\title{
Urban heat island modelling based on MUKLIMO: examples from Slovakia
}

\author{
Monika Kopecká (corresponding author), Daniel Szatmári ${ }^{\mathrm{a}}$, Juraj Holec ${ }^{\mathrm{b}}$ and Ján Feranec ${ }^{\mathrm{a}}$ \\ monika.kopecka@savba.sk, daniel.szatmari@ savba.sk, feranec@savba.sk, juraj.holec@shmu.sk
}

${ }^{a}$ Institute of Geography, Slovak Academy of Sciences, Bratislava, Slovakia

${ }^{\mathrm{b}}$ Slovak Hydrometeorological Institute, Bratislava, Slovakia

\begin{abstract}
Cities are generally expected to experience higher temperatures than surrounding rural areas due to the Urban Heat Island (UHI) effect. The aim of this paper is to document identification and delimitation of land cover/land use (LC/LU) classes based on Urban Atlas data in three cities in Slovakia: the capital Bratislava and two regional centres, Trnava and Žilina, in the years 1998-2016 and their effect on the temperature change. The concept of Local Climate Zones (replaced by LC/LU classes in this study) was used as an input for the UHI modelling by application of the Mikroskaliges Urbanes KLIma MOdell (MUKLIMO). The model MUKLIMO was validated by data taken in five stations in Bratislava, two in Trnava, and one in Žilina, while a good rate of agreement between the modelled and measured data was statistically proved. A single representative day (August 22, 2018) was chosen for which UHI was modelled with three inputs of LC/LU classes: situation in 1998, 2007, and 2016 to assess the effect of change of LC/LU classes on the distribution of temperatures. The spatial manifestation of UHI was assessed in the frame of LC/LU classes for 2016 at 21:00 of Central European Summer Time (CEST). The results indicate that UHI intensity trends are spatially correlated with LC/LU classes and their change pattern. Results of Bratislava show, regarding the size of the city and relief dissection, greater variability than smaller Trnava situated in flat terrain and Žilina situated in the river valley surrounded by the mountain ranges.
\end{abstract}

Keywords: urban heat island (UHI), MUKLIMO, Urban Atlas, Slovakia

\section{Introduction}

Climate change is expected to increase the frequency and duration of excessive heat events, especially in cities. The urban heat island (UHI) - a phenomenon in which temperature tends to be higher in urban landscape than surrounding non-urban areas has been observed worldwide. Over the last few decades, advancements in remote sensing increased the number of UHI studies that can be classified into two broad categories: "air" (or "atmospheric") and "surface" UHIs (Zhou et al., 2019). Air UHI refers to UHI effects in the canopy (CLHI) or boundary (BLHI) layer (Oke, 1995). The CLHI is usually measured by in situ sensors on the fixed meteorological stations or traverses of vehicles while more special platforms (aircrafts, radiosondes, etc.) are needed to measure the BLHI. On the other hand, surface UHI (SUHI) represents the radiative temperature difference between urban and non-urban surfaces measured by satellite thermal remote sensing data. SUHI usually develops during hot, sunny summer days. The sun heats dry, exposed urban surfaces, like roofs, roads, and pavements, to temperatures 25 to $50{ }^{\circ} \mathrm{C}$ higher than the temperature of the ambient air mass (Hofierka et al., 2020).

UHI mitigation requires understanding of factors affecting the interaction between solar radiation and urban land cover classes (Majkowska et al., 2017). It is obvious from many studies that the LC/LU classes and their changes influence the frequency and intensity of the UHI. Oke (2004) proposed a simple classification of what are referred to as urban climate zones (UCZs), which roughly correspond to LC/LU classes.

The aim of the paper is to use LC/LU classes based on Urban Atlas (UA) data in three cities in Slovakia: the capital Bratislava and two regional centres, Trnava and Žilina (located in different geographical conditions), in the years 1998-2016 and document the impact of their changes on the air temperature difference by application of MUKLIMO_3. This model has been used for the studies of UHI in various cities, e.g. Vienna (Žuvela-Aloise et al., 2014), Brno (Geletič et al., 2018), Bratislava and Trnava (Holec and Št’astný, 2017; Holec et al., 2020), Szeged (Gál and 
Skarbit, 2017) or comparison of five central European cities (Bokwa et al., 2015; Bokwa et al., 2019).

\section{Methodology}

The increasing availability of high-resolution geospatial data allows the development of multiple modelling approaches in urban areas. MUKLIMO_3 was applied in this study for UHI modelling. This three-dimensional model was developed for the microscale applications aimed at the issues of urban climate, primarily the UHI mapping (Sievers and Zdunkowski, 1985). The algorithm of the model includes prognostic equations for air temperature and humidity, parametrisation of undetermined buildings, short and long-wave radiation, soil temperature and moisture balance, as well as the vegetation model. It also uses the categorisation of proportions of surfaces of varied kinds by an established scale: built-up, impermeable and permeable surface parts like vegetation cover, and soil (Sievers et al., 1983). The model allows working with up to 99 user-defined LC/LU classes and grid resolution in tens to hundreds of meters. A horizontal resolution of $100 \mathrm{~m}$ was selected for this study. This resolution is higher than other urban climate models, e.g. the WRF model works with resolution in kilometres for UHI studies (Giannaros et al., 2013).

\subsection{Software and Data Availability}

MUKLIMO_3 is a product of the German Weather Service (DWD) available upon request for noncommercial research and teaching purposes. The model predicts air temperature, relative humidity, wind speed and direction, and soil and surface temperatures. Model outputs can be converted into NetCDF format and postprocessed in GIS software. In this study, QGIS 3.6.3-Noosa was used for model outputs postprocessing. Python console within QGIS environment was used for raster calculator operations running iteratively for three cities and more extracted hours. Model MUKLIMO_3 can be used to simulate the impact of planned changes on the local or regional climate, namely, the effects of different climate change adaptation measures, including the implementation of green infrastructure or unsealing of sealed surfaces (e.g. Žuvela-Aloise et al., 2016).

Several model inputs are necessary: layers of digital elevation model, LC/LU data, and meteorological inputs (Tab. 1). SRTM DEM (Shuttle Radar Topography Mission Digital Elevation Model) with 90- meter resolution was used as a source of elevation data (Jarvis et al., 2008). This model is freely available after registration via USGS Earth Explorer (https://earthexplorer.usgs.gov/). The model was subsequently recalculated into 100-meter resolution.

Table 1: Input data to the MUKLIMO model.

\begin{tabular}{|l|l|}
\hline Input data & Data specification \\
\hline $\begin{array}{l}\text { Digital Elevation } \\
\text { Model }\end{array}$ & SRTM DEM \\
\hline $\begin{array}{l}\text { Land Use/Land Cover } \\
\text { data }\end{array}$ & $\begin{array}{l}\text { Urban Atlas data 2012, SPOT } \\
\text { 2/1998, SPOT 5/2007, Sentinel- }\end{array}$ \\
\hline HRL Imperviousness & HRL Imperviousness 2012 \\
\hline Meteorological data & $\begin{array}{l}\text { Data from the period August 15 } \\
-24,2018 \text { (Bratislava, Jaslovské } \\
\text { Bohunice and Dolný Hričov) }\end{array}$ \\
\hline Urban Greenery data & SPOT \\
\hline Building layer & ZBGIS database \\
\hline
\end{tabular}

The Urban Atlas (UA) provides pan-European reliable, inter-comparable, high-resolution LC/LU data for 305 Functional Urban Areas (FUA) with more than 100,000 inhabitants for the 2006 reference year and 785 FUA with more than 50,000 inhabitants for the 2012 reference year in EEA39 countries. They are mainly based on the combination of (statistical) image classification and computer assisted photointerpretation (CAPI; Feranec et al., 2016) of Very High Resolution satellite imagery (e.g. multispectral SPOT $5 \& 6$ and Formosat-2 pan-sharpened imagery with a 2 to $2.5 \mathrm{~m}$ spatial resolution). The nomenclature includes 17 urban classes with a minimum mapping unit (MMU) of 0.25 ha and 10 rural classes with MMU 1 ha (Meirich, 2008; Urban Atlas, 2012). These data are available after registration on https://land.copernicus.eu/local/urbanatlas. Boundaries of UA 2012 classes were modified using backdating according to the SPOT-4/1998, SPOT-5/2007, Sentinel-2/2016 satellite images by CAPI. They were further specified by building heights and parking areas using ZBGIS data (ZBGIS is a spatial object-oriented database that is a reference basis of the National Spatial Data Infrastructure created and maintained by the Geodesy Cartography and Cadastre Authority of the Slovak Republic), and data about the urban greenery (woody vegetation, grass vegetation or mixed vegetation (trees and grass) prevails outside the sealed areas) obtained by supervised classification of the quoted satellite images. Copernicus Imperviousness high resolution layer was used to specify soil sealing degree of LC/LU data. In this way, 53 classes of prevailingly urban landscape (according to the intensity of impermeable surfaces), farming landscape, semi-natural landscape, forest landscape, 
waterlogged areas, and waters were derived (Tab. 2; Szatmári et al., 2018). Areas of these classes identified for the years 1998, 2007, and 2016 were the input data for the MUKLIMO model. Due to the technical requirements of the model, a regular cut-out from FUA was used.

August 22, 2018, was chosen for modelling with the MUKLIMO model. This day was one of the days during the summer heatwave from August 15 to August 24, 2018. The centre of anticyclone was moving from Poland to Slovakia. Maximum temperature of $32.2^{\circ} \mathrm{C}$ in Bratislava, $33.2{ }^{\circ} \mathrm{C}$ in Jaslovské Bohunice station near Trnava, and $30.8^{\circ} \mathrm{C}$ in Dolný Hričov station near Žilina were measured during the model day. Wind speed moved from 1 up to $4 \mathrm{~m} / \mathrm{s}$, and cloudiness was below $10 \%$.

\section{Table 2: Extended nomenclature UA 2012.}

\section{Artificial surfaces}

1.1 Urban fabric

1.1.1 Continuous urban fabric-soil sealing degree $>80 \%$

1.1.1.1.0* Building height $\leq 5 \mathrm{~m}$

1.1.1.2.0* Building height $5.1-10 \mathrm{~m}$

1.1.1.3.0* Building height $10.1-15 \mathrm{~m}$

1.1.1.4.0* Building height $15.1-20 \mathrm{~m}$

1.1.1.5.0* Building height $>20 \mathrm{~m}$

1.1.1.6.0* Mixed building heights

1.1.2 Discontinuous urban fabric-soil sealing degree $\leq 80 \%$

1.1.2.1 Discontinuous dense urban fabric-soil sealing degree $=51-80 \%$

1.1.2.1.1* Building height $\leq 5 \mathrm{~m}$

1.1.2.1.2* Building height $5.1-10 \mathrm{~m}$

1.1.2.1.3* Building height $10.1-15 \mathrm{~m}$

1.1.2.1.4* Building height $15.1-20 \mathrm{~m}$

1.1.2.1.5* Building height $>20 \mathrm{~m}$

1.1.2.1.6* Mixed building heights

1.1.2.2 Discontinuous medium-density urban fabric-soil sealing degree $=31-50 \%$

1.1.2.2.1* Building height $\leq 5 \mathrm{~m}$

1.1.2.2.2* Building height $5.1-10 \mathrm{~m}$

1.1.2.2.3* Building height $10.1-15 \mathrm{~m}$

1.1.2.2.4* Building height $15.1-20 \mathrm{~m}$

1.1.2.2.5* Building height $>20 \mathrm{~m}$

1.1.2.2.6* Mixed building heights

1.1.2.3 Discontinuous low density urban fabric-soil sealing degree $=11-30 \%$

1.1.2.3.1* Building height $\leq 5 \mathrm{~m}$

1.1.2.3.2* Building height $5.1-10 \mathrm{~m}$

1.1.2.3.3* Building height $10.1-15 \mathrm{~m}$

1.1.2.3.4* Building height $15.1-20 \mathrm{~m}$

1.1.2.3.5* Building height $>20 \mathrm{~m}$

1.1.2.3.6* Mixed building heights

1.1.2.4 Discontinuous very low density urban fabric-soil sealing degree $\leq 10 \%$

1.1.2.4.1* Building height $\leq 5 \mathrm{~m}$
1.1.2.4.2* Building height 5.1-10 m

1.1.2.4.3* Building height $10.1-15 \mathrm{~m}$

1.1.2.4.4* Building height 15.1-20 m

1.1.2.4.5* Building height $>20 \mathrm{~m}$

1.1.2.4.6* Mixed building heights

1.1.3.0.0* Isolated structures

1.2 Industrial, commercial, and transportation units

1.2.1 Industrial, commercial, public, military, private areas

1.2.1.1.0* Schools, hospitals, shopping areas, and administrative

1.2.1.2.0* Production and warehouse areas

1.2.2 Road and railway networks and associated land

1.2.2.1.0* Fast transit roads and associated land

1.2.2.2.0* Other roads and associated land

1.2.2.3.0* Railways and associated land

1.2.3.0.0* Port areas

1.2.4.0.0* Airports

1.3 Mine, dump, and construction sites

1.3.1.0.0* Mineral extraction and dump sites

1.3.3.0.0* Construction sites

1.3.4.0.0* Land without current use

1.4 Artificial non-agricultural vegetated areas

1.4.1.0.0* Green urban areas

1.4.2.0.0* Sport and leisure facilities

2. Agricultural areas

2.1.0.0.0.0 Arable land-annual crops

2.2.0.0.0.0 Permanent crops

2.3.0.0.0.0 Pastures

2.4.0.0.0.0 Complex and mixed cultivation patterns

2.5.0.0.0.0 Orchards

3. Forest

3.1.0.0.0.0 Forests

3.2.0.0.0.0 Herbaceous vegetation

3.3.0.0.0.0 Open space with little or no vegetation

4.0.0.0.0.0 Wetlands

\subsection{Water}

*The class includes one of three types of vegetation:

class code +1 : woody vegetation prevails outside sealed areas; class code+2: grass vegetation prevails outside sealed areas;

class code +3 : mixed vegetation prevails outside sealed areas; class code +0 : no vegetation.

Meteorological inputs gained from databases of the Slovak Hydrometeorological Institute (SHMI) comprised air temperature, humidity, and soil and water temperature. Bratislava-Letisko station, located on the periphery of Bratislava, was chosen as the input station for UHI modelling in Bratislava. Jaslovské Bohunice station, $13 \mathrm{~km}$ distant from the town of Trnava, was selected for Trnava and Dolný Hričov, $8 \mathrm{~km}$ from the town of Žilina, was chosen for Žilina. As the MUKLIMO model needs temperature and humidity inputs in vertical profile, data from upper height levels (several hundred metres) were obtained from aerologic measurements from Vienna, Hohe Warte station, $55 \mathrm{~km}$ from Bratislava and $90 \mathrm{~km}$ from Trnava. For Žilina, the ALADIN numerical weather 
prediction model outputs were used as upper height level input. Archived meteorological data from SHMI are available upon request for a charge. Upper air meteorological measurements are available via the University of Wyoming webpage (http://weather.uwyo.edu/upperair/sounding.html). The same meteorological situation was modelled twice: with LC/LU classes for years 2016 and 1998. This alteration and subsequent subtraction using raster calculator in QGIS was performed in order to express the temperature differences caused by LC/LU changes between 1998 and 2016.

Meteorological, air pollution monitoring, and precipitation stations measuring temperature from the SHMI network were used for model validation. Index of Agreement (Wilmott, 1981) was used to assess the model fitting. Hourly measured data from meteorological stations were compared with hourly modelled data, i.e. 24 observation / model couples were input into Index of Agreement.

\section{Study areas}

UHIs were identified in Bratislava, Trnava, and Žilina, three of eight regional capitals of Self-Governing Regions (NUTS 3) in Slovakia (Fig. 1). Due to intensive industrial and commercial development, these cities experienced the greatest rates of LC/LU change in the last two decades in the country. The cities of Bratislava and Žilina are located in large river valleys, and the diversified terrain is an important local climate factor. The city of Trnava is located in a flat area. The built-up area of the cities has increased significantly in recent twenty years due to the construction of new automobile plants (Peugeot-Citroën in Trnava and Kia Motors in Žilina) and large shopping centres in suburban areas (Appendix 1). The Bratislava study area is situated in the south-west part of Slovakia, bordering Austria in the west and Hungary in the south. Bratislava is the capital of Slovakia, the country's largest city and its political, cultural, and economic centre. Due to this fact and a good quality transport infrastructure, it is a territory with a high potential for territorial development. The limiting factor for further expansion of the city is the Little Carpathian mountain range located north of the city centre. Bratislava lies on both banks of the Danube River, which crosses the city from the west to the south-east. The population of Bratislava by the end of 2018 was 431,065 inhabitants ( $7.91 \%$ of the population in Slovakia).

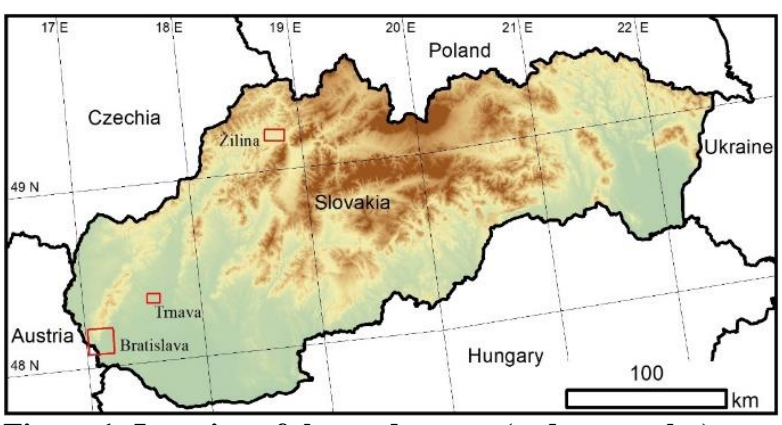

Figure 1: Location of the study areas (red rectangles).

Trnava is a city in western Slovakia, $47 \mathrm{~km}$ north-east of Bratislava. It is located in the Danubian Lowland on the Trnávka River in the central part of Trnava Plain. Due to the character of relief, the close position to the capital city of Bratislava, and good transport infrastructure, it has a great potential for territorial development. However, the presence of top quality soils in the hinterland of the city is actually a limiting factor for its further expansion. The population of Trnava by the end of 2018 was 65,207 inhabitants. Žilina is a city in north-western Slovakia, around 200 kilometres from the capital Bratislava, close to both the Czech and Polish borders. It is the fourth largest city of Slovakia with a population of 80,810 ; an important industrial centre, and the largest city on the Váh River. The city is surrounded by the mountain ranges Malá Fatra, Súlovské vrchy, Javorniky, and Kysucká vrchovina. Proportion of land cover classes in all three study areas in 2018 is presented in Tab. 3 .

Table 3: Land cover classes in 2018 in the study areas.

\begin{tabular}{|c|c|c|c|c|c|c|}
\hline \multirow{2}{*}{$\begin{array}{c}\mathrm{LC} / \mathrm{LU} \\
\text { class }\end{array}$} & \multicolumn{2}{|c|}{ Bratislava } & \multicolumn{2}{|c|}{ Trnava } & \multicolumn{2}{|c|}{ Ži i i n a } \\
\hline & $\begin{array}{l}\text { Class } \\
\text { area } \\
\text { perc. }\end{array}$ & $\begin{array}{c}\text { Prevailing } \\
\text { building } \\
\text { height }\end{array}$ & $\begin{array}{c}\text { Class } \\
\text { area } \\
\text { perc. }\end{array}$ & $\begin{array}{c}\text { Prevailing } \\
\text { building } \\
\text { height }\end{array}$ & $\begin{array}{l}\text { Class } \\
\text { area } \\
\text { perc. }\end{array}$ & $\begin{array}{c}\text { Prevailing } \\
\text { building } \\
\text { height }\end{array}$ \\
\hline 1.1 .1 & $0.7 \%$ & $>20 \mathrm{~m}$ & $0.0 \%$ & & $0.3 \%$ & $15.1-20 \mathrm{~m}$ \\
\hline 1.1.2.1 & $4.4 \%$ & $>20 \mathrm{~m}$ & $1.1 \%$ & $5.1-10 \mathrm{~m}$ & $4.4 \%$ & $5.1-10 \mathrm{~m}$ \\
\hline 1.1 .2 .2 & $6.1 \%$ & $5.1-10 \mathrm{~m}$ & $10.2 \%$ & $5.1-10 \mathrm{~m}$ & $9.9 \%$ & $5.1-10 \mathrm{~m}$ \\
\hline 1.1.2.3 & $3.6 \%$ & $5.1-10 \mathrm{~m}$ & $1.0 \%$ & $5.1-10 \mathrm{~m}$ & $0.9 \%$ & $5.1-10 \mathrm{~m}$ \\
\hline 1.1.2.4 & $2.9 \%$ & $\leq 5 \mathrm{~m}$ & $0.7 \%$ & $\leq 5 \mathrm{~m}$ & $1.5 \%$ & $\leq 5 \mathrm{~m}$ \\
\hline 1.2 & $22.3 \%$ & & $21.9 \%$ & & $16.1 \%$ & \\
\hline 1.3 & $1.8 \%$ & & $3.9 \%$ & & $1.7 \%$ & \\
\hline 1.4 & $6.3 \%$ & & $4.7 \%$ & & $3.2 \%$ & \\
\hline 2 & $22.2 \%$ & & $54.9 \%$ & & $32.6 \%$ & \\
\hline 3 & $26.4 \%$ & & $0.5 \%$ & & $24.7 \%$ & \\
\hline 4 & $0.0 \%$ & & $0.4 \%$ & & $0.1 \%$ & \\
\hline 5 & $3.3 \%$ & & $0.7 \%$ & & $4.6 \%$ & \\
\hline & $100.0 \%$ & & $100.0 \%$ & & $100.0 \%$ & \\
\hline
\end{tabular}

\section{Results}

Due to intensive industrial and commercial development, cities Bratislava, Trnava, and Žilina 
experienced the greatest rates of $\mathrm{LC} / \mathrm{LU}$ change in the last two decades in the country, especially urban expansion: Bratislava -662.95 ha, Trnava -527.25 ha, Žilina - 448.03 ha and cultivated land reduction: Bratislava - 671.78 ha, Trnava - 527.25 ha, Žilina 444.15 ha).

Results from model validation show generally good fitting between model and field measurements in selected stations with an Index of agreement between 0.85 for Žilina and 0.97 in Bratislava - Mlynská dolina and Trnava - Biely Kostol (Tab. 4). No further geospatial analysis was performed on the data due to sparse network of meteorological stations. Correct geospatial analysis would require denser network of measurement points.

Table 4: Index of agreement between model and field measurements of air temperature in selected meteorological stations.

\begin{tabular}{|l|c|}
\hline \multicolumn{1}{|c|}{ Meteorological station } & $\begin{array}{c}\text { Index of } \\
\text { agreement }\end{array}$ \\
\hline Bratislava - Koliba (KOL) & 0.90 \\
\hline Bratislava - letisko (LET) & 0.96 \\
\hline Bratislava - Mamateyova (MAM) & 0.95 \\
\hline Bratislava - Mlynská dolina (MLY) & 0.97 \\
\hline Bratislava - Trnavské mýto (TMY) & 0.88 \\
\hline Trnava - centrum (TTC) & 0.96 \\
\hline Trnava - Biely Kostol (TBK) & 0.97 \\
\hline Žilina (ZIL) & 0.85 \\
\hline
\end{tabular}

Graphs of measured and modelled daily temperature course are depicted in Fig. 2. Underestimation of daily maximum temperature can be observed from the graphs. It can be caused by various reasons: e.g. advection of warm air masses which is omitted by the model, or difference between vertical profile from nearest available aerological station and real temperature over the surface layer of atmosphere in the study area. In the case of Žilina, the measured nocturnal cooling is more distinct than in the modelled temperature course, which can be addressed to lower accuracy of the model in this time of day (Geletič et al., 2016) and the area of a domain that does not cover all of the adjacent mountain ranges; thus the katabatic flows are probably underrated.

Since the effect of UHI is the strongest during the evening and night hours, the results at 21:00 CEST were used for showing the UHI pattern, and LC/LU changes effect on UHI (Appendix 2). The most intensive UHI effect can be observed in the biggest of three cities - Bratislava. The difference between the city-centre and the adjacent countryside is up to $4{ }^{\circ} \mathrm{C}$. The warmest area extends from the city centre to the eastern direction. The western part of the city has a less distinct UHI pattern due to more dissected relief with higher altitude. Areas with the presence of forests (LC/LU 31000) are even colder than countryside with prevailing arable land (LC/LU 21000). The role of the land surface must be taken into account - the coldest part of the model domain is the valley of Vydrica river in the Little Carpathian mountain range with temperature inversion - the modelled temperature is approximately $21^{\circ} \mathrm{C}$. Considering the combined effect of UHI and land surface, the temperature span is up to $8{ }^{\circ} \mathrm{C}$ at 21:00 CEST in Bratislava.

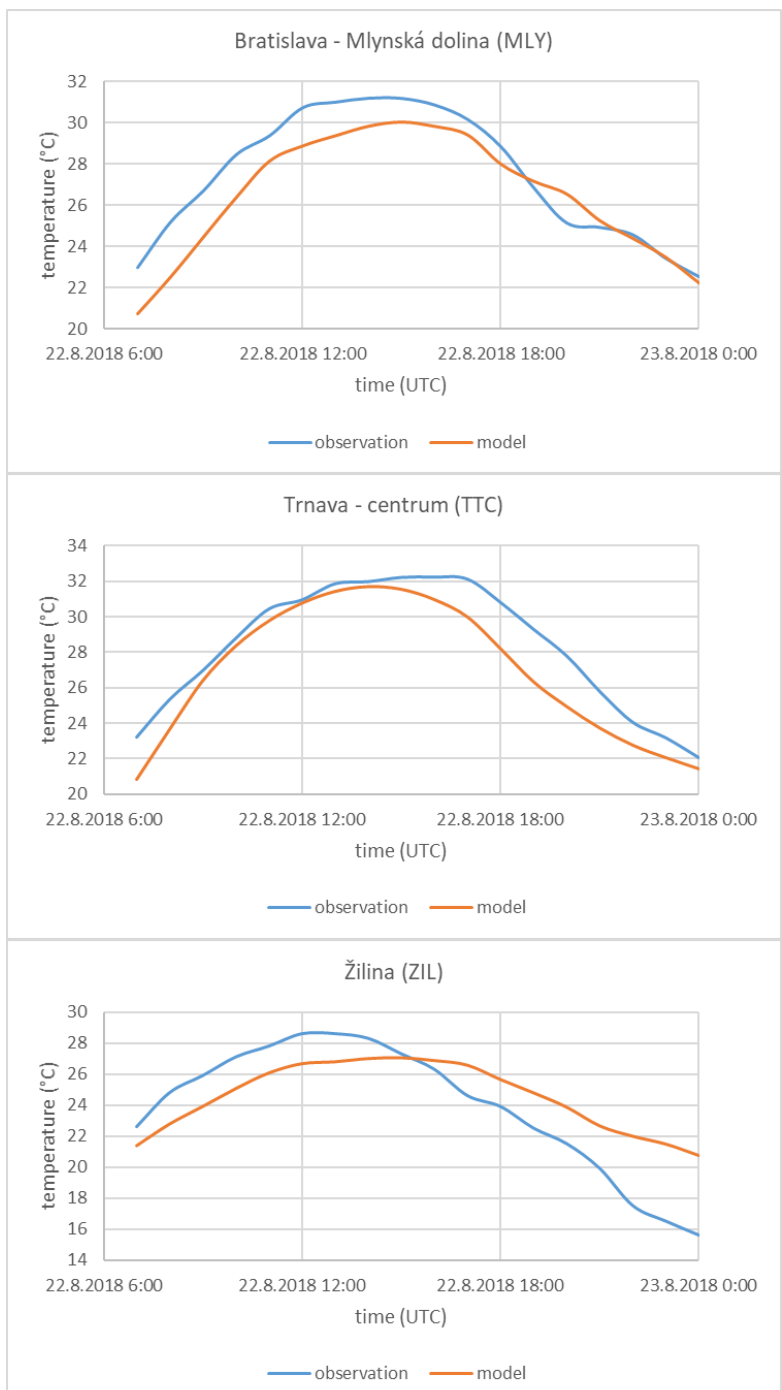

Figure 2: Measured and modelled temperature course in selected meteorological stations.

In comparison with Bratislava, Trnava is a smaller town, which lies within relatively homogenous relief. Differences between city and countryside reach up to $2.5^{\circ} \mathrm{C}$. It has to be noted that UHI does not copy the urbanised area strictly. The reason can be found in air 
flowing which was the strongest for selected three cities and shifted the UHI southwards.

Žilina is in the mountainous area of northern Slovakia, so the results show the combined effect of relief and UHI. The effect of UHI causes a difference up to $1.5{ }^{\circ} \mathrm{C}$ in comparison with the countryside at a similar altitude. Considering the various $\mathrm{LC} / \mathrm{LU}$ and more complex relief, there can be found areas up to $4{ }^{\circ} \mathrm{C}$ colder than city-centre.

Differences between LC/LU in 1998 and 2016 (Appendix 3) cause different temperatures (Appendix 4). The model shows the rising temperature for areas with change into artificial surfaces in all three cities, usually in tenths of ${ }^{\circ} \mathrm{C}$, in several places up to more than $1{ }^{\circ} \mathrm{C}$. These changes can spread into surrounding space due to air fluxes. On the other hand, the cooling effect, usually in tenths of ${ }^{\circ} \mathrm{C}$, is modelled in the areas with change into areas without use, pastures, and green areas.

\section{Conclusion}

The interaction of solar irradiance with urban surfaces is the main source of urban heat islands. LC/LU changes between the years 1998, 2007, and 2016 have shown their effect on the temperature change. It was confirmed that urbanisation causes further warming of the territory. Like the scope of the change, the surroundings of the changed area and its physiogeographical position play their roles. Diurnal variability and spatial distribution of air temperature were studied in three cities in Slovakia: Bratislava, Trnava, and Žilina.

The studies concerning the impact of global changes on the local climate of cities are of high significance for the urban inhabitants' health and wellbeing. To plan and undertake the mitigation actions in particular cities is necessary to recognize the possible range of heat increase and its spatial extent. Visualisation of the UHI effect and its changes using MUKLIMO improves the perception of the relationship between LC/LU classes and the UHI.

\section{Acknowledgement}

This paper was supported by the Slovak Research and Development Agency under the contract no. APVV15-0136 "Effect of impermeable soil cover on urban climate in the context of climate change" and VEGA
Grant Agency No. 2/0023/19 Land Cover Dynamics as indicator of changes in landscape.

\section{References}

Bokwa, A., Dobrovolný, P., Gál, T., Geletič, J., Gulyás, A., Hajto, M. J., Hollósi, B., Kielar, R., Lehnert, M., Skarbit, N., Št’astný, P., Švec, M., Unger, J., Vysoudil, M., Walawender, J. P., Žuvela-Aloise, M. Modelling the impact of climate change on heat load increase in Central European cities, $9^{\text {th }}$ International Conference on Urban Climate (ICUC 9)., www.meteo.fr/icuc9/LongAbstracts/ccma2-53151332_a.pdf, 2015.

Bokwa, A., Geletič, J., Lehnert, M., Žuvela-Aloise, M., Hollósi, B., Gál, T., Skarbit, N., Dobrovolný, P., Hajto, M. J., Kielar, R., Walawender, J. P., Št’astný, P., Holec, J., Ostapowicz, K., Burianová, J., Garaj, M. Heat load assessment in Central European cities using an urban climate model and observational monitoring data, Energy and Buildings., 201, 53-69, https://doi.org/10.1016/j.enbuild.2019.07.023, 2019.

Feranec, J., Hazeu, G., Soukup, T. Interpretation of satelite images. In Feranec, J., Soukup, T., Hazeu, G., Jaffrain, G. (eds.): European Landscape dynamics: CORINE land cover data., Boca Raton: CRC Press, Taylor \& Francis Group, 33-40, 2016.

Gál, T., Skarbit, N. Applying local climate zones as land use classes in MUKLIMO_3 for modelling urban heat load in the case of Szeged, Hungary. In: Buchholz, S., Noppel, H., Žuvela-Aloise, M., Hollósi, B. (eds.): 1st MUKLIMO_3 Users Workshop Programme and book of abstracts, 30 p, 2017.

Geletič, J., Lehnert, M., Dobrovolný, P. Modelled spatio-temporal variability of air temperature in an urban climate and its validation: a case study of Brno, Czech Republic, Hungarian Geographical Bulletin., 65, 169-180, https://doi.org/10.15201/hungeobull.65.2.7, 2016.

Geletič, J., Lehnert, M., Savić, S., Milošević, D. Modelled spatiotemporal variability of outdoor thermal comfort in local climate zones of the city of Brno, Czech Republic, Science of the Total Environment., 624, 385-395, https://doi.org/10.1016/j.scitotenv.2017.12.076, 2018.

Giannaros, T. M., Melas, D., Daglis, I. A., Keramitsoglou, I., Kourtidis, K. Numerical study of the urban heat island over Athens (Greece) with the WRF 
model, Atmospheric Environment., 73, 103-111, https://doi.org/10.1016/j.atmosenv.2013.02.055, 2013.

Hofierka, J., Gallay, M., Onačillová, K., Hofierka, Jr., J. Physically-based land surface temperature modeling in urban areasusing a 3-D city model and multispectral satellite data, Urban Climate., 31, 100566, https://doi.org/10.1016/j.uclim.2019.100566, 2020.

Holec, J., Št’astný, P. Modelovanie mestského ostrova tepla v Bratislave pomocou modelu MUKLIMO, Meteorologický časopis., 20, 65-72, ISSN 1335-339X, 2017.

Holec, J., Feranec, J., Št’astný, P., Szatmári, D., Kopecká, M., Garaj, M. Evolution and assessment of urban heat island between the years 1998 and 2016: case study of the cities Bratislava and Trnava in western Slovakia, Theoretical and Applied Climatology., 141, 979-997, https://doi.org/10.1007/s00704-020-03197-1, 2020.

Jarvis, A., Reuter, H. I., Nelson, A., Guevara, E. Holefilled SRTM for the globe Version 4, 15, 25-54, http://srtm.csi.cgiar.org, 2008.

Lauriola, P. Introduction. In: Musco, F. (ed.): Counteracting urban heat Island effects in a global climate change scenario. Springer: eBook, xlvii-liii, 2016.

Majkowska, A., Kolendowicz, L., Pólrolniczak, M., Hauke, J., Czernecki, B. The urban heat island in the city of Poznan as derived from Landsat 5 TM, Theoretical and Applied Climatology., 128, 769-783, https://doi.org/10.1007/s00704-016-1737-6, 2017.

Meirich, S. Mapping guide for a European Urban Atlas, GSE Land Consortium. Report ITD-0421GSELand-TN-01. http://www.eea.europa.eu/data-andmaps/data/urban-atlas/mapping-guide, 2008.

Oke, T. R. The heat island characteristics of the urban boundry layer. Characteristics, causes and effects. In: Cermak, J. E., Davenport, A. G., Plate, E. J., Viegas, D. X. (eds.): Wind Climate in Cities., Kluwer Academic, Norwel, 81-107, 1995.

Oke, T. R. Initial guidance to obtain representative meteorological observations at urban sites, instruments and methods of observation programme, IOM Report No. 81, WMO/TD No. 1250. World Meteorological Organization, Geneva, 2004.

Sievers, U., Forkel, R., Zdunkowski, W. Transport equations for heat and moisture in the soil and their application to boundary layer problems, Beiträge Physik der Atmosphäre., 56, 58-83, 1983.

Sievers, U., Zdunkowski, W. A numerical simulation scheme for the albedo of city street canyons, Boundary-Layer Meteorology., 33, 245-257, 1985.

Szatmári, D., Kopecká, M., Feranec, J., Sviček, M. Extended nomenclature Urban Atlas 2012 (APVV-150136)., Institute of Geography Slovak Academy of Sciences, Bratislava, pp.48 ISBN: 978-80-89548-06-4, http://www.geography.sav.sk/webdata/news/monografie/2018_rozsirena_legenda_urban_ atlas_2012.pdf, 2018.

Urban Atlas., https://land.copernicus.eu/local/urbanatlas, 2012.

Willmott, C. J. On the validation of models, Physical Geography., 2, 184-194, 1981.

Zhou D., Xiao, J., Bonafoni, S., Berger, Ch., Deilami, K., Zhou, Y., Frolking, S., Yao, R., Qiao, Z., Sobrino, J. A. Satellite Remote Sensing of Surface Urban Heat Islands: Progress, Challenges, and Perspectives, Remote Sensing., 11, 48, https://doi.org/10.3390/rs11010048, 2019.

Žuvela-Aloise, M., Koch, R., Neureiter, A., Böhm, R., Buchholz, S. Reconstructing urban climate of Vienna based on historical maps dating to the early instrumental period, Urban Climate., 10, 490-508, https://doi.org/10.1016/j.uclim.2014.04.002, 2014.

Žuvela-Aloise, M., Koch, R., Buchholz, S., Früh, B. Modelling the potential of green and blue infrastructure to reduce urban heat load in the city of Vienna, Climatic Change., 135, 425-438, https://doi.org/10.1007/s10584-016-1596-2, 2016. 
Appendix 1: Spatial distribution of LC/LU classes in the year 2016 (extended Urban Atlas 2012; Szatmári et al., 2018).
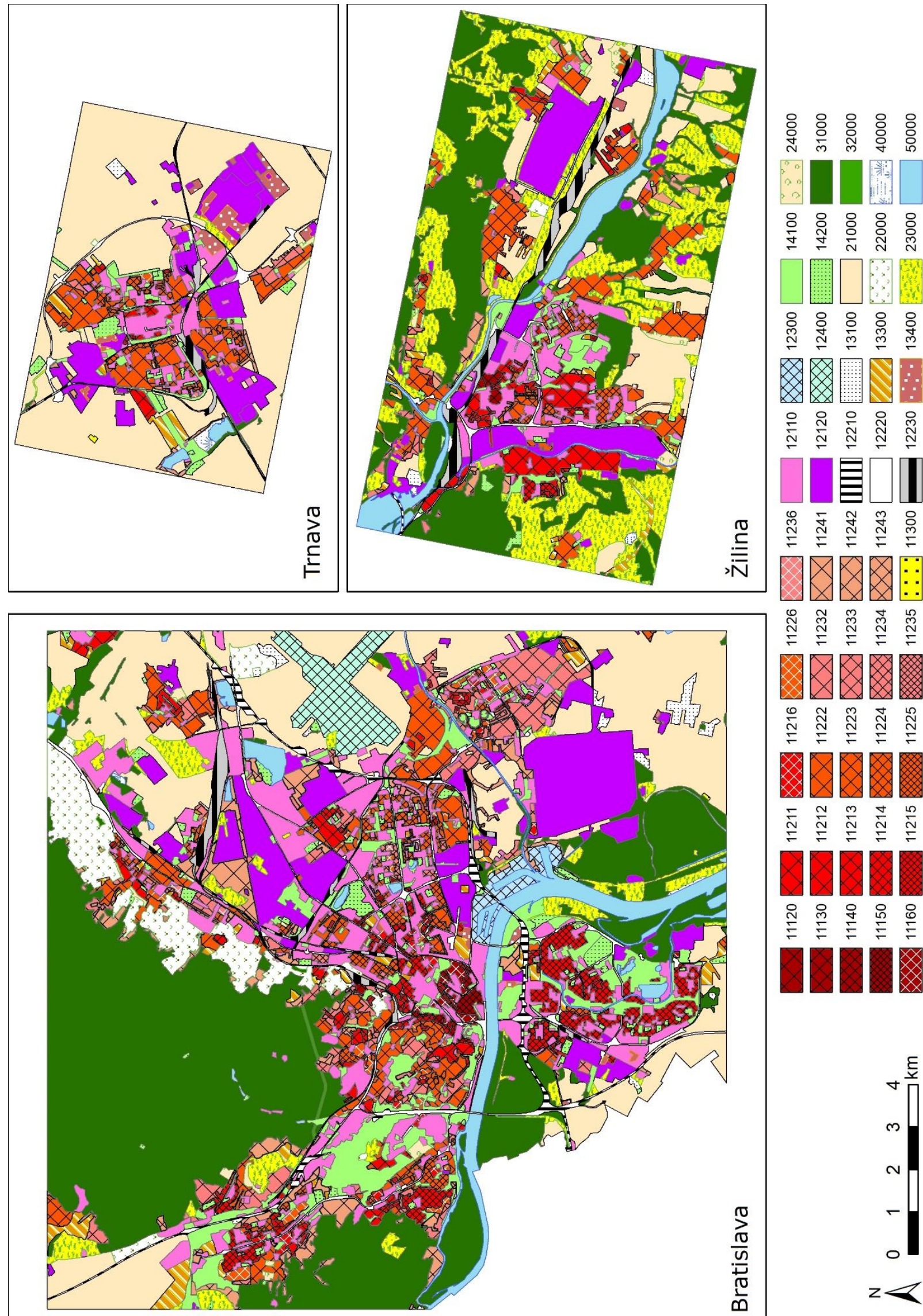

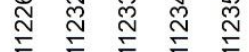

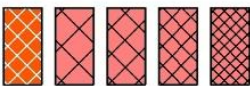

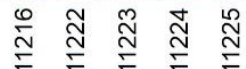

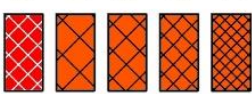

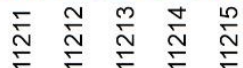

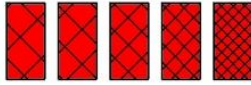

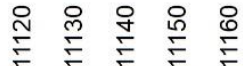

Q⿻

$\frac{20}{\frac{\pi}{0}}$

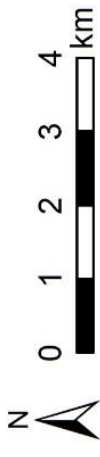


Appendix 2: Spatial distribution of temperatures for modelled day August 22, 2018 at 21:00 CEST.
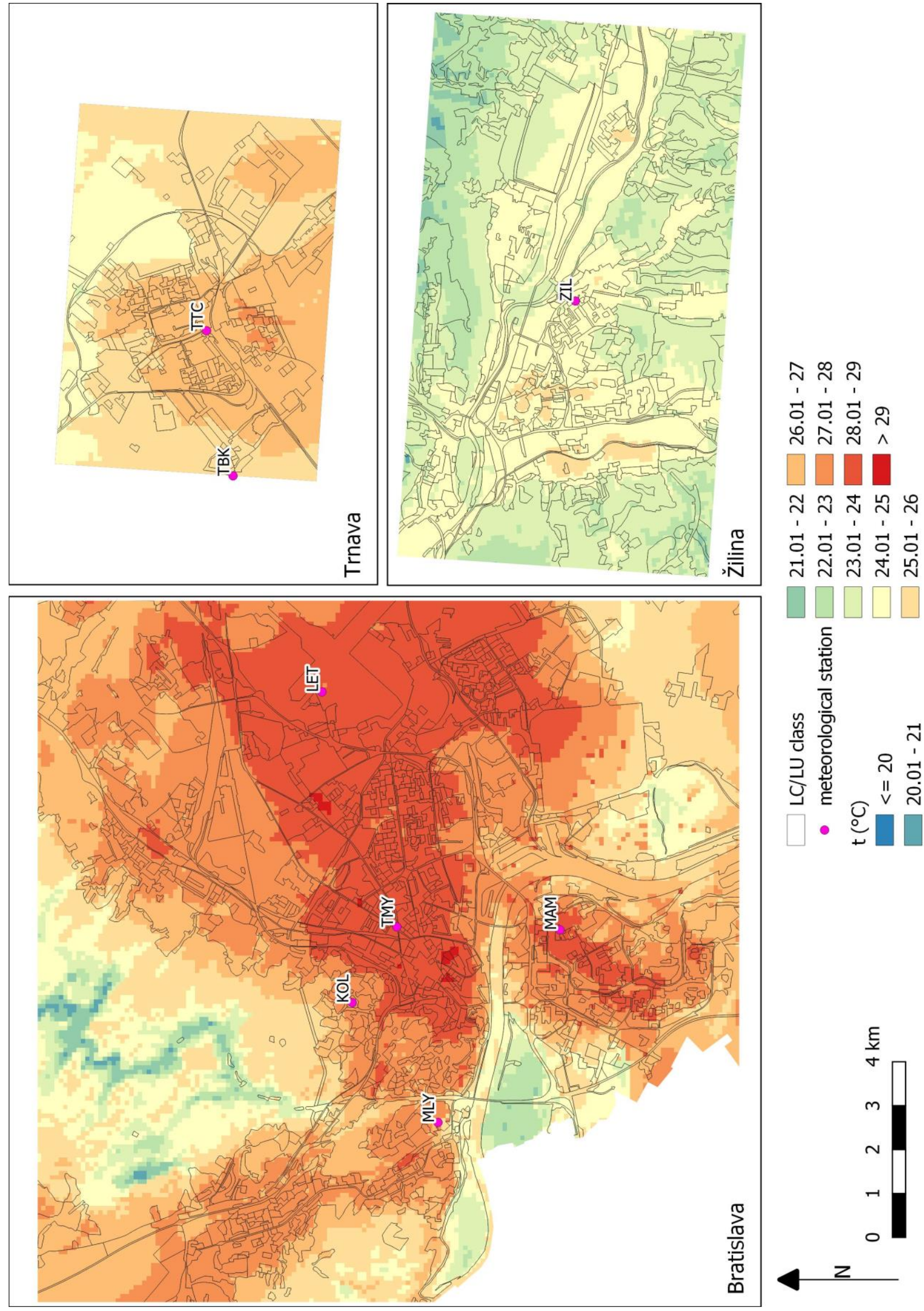

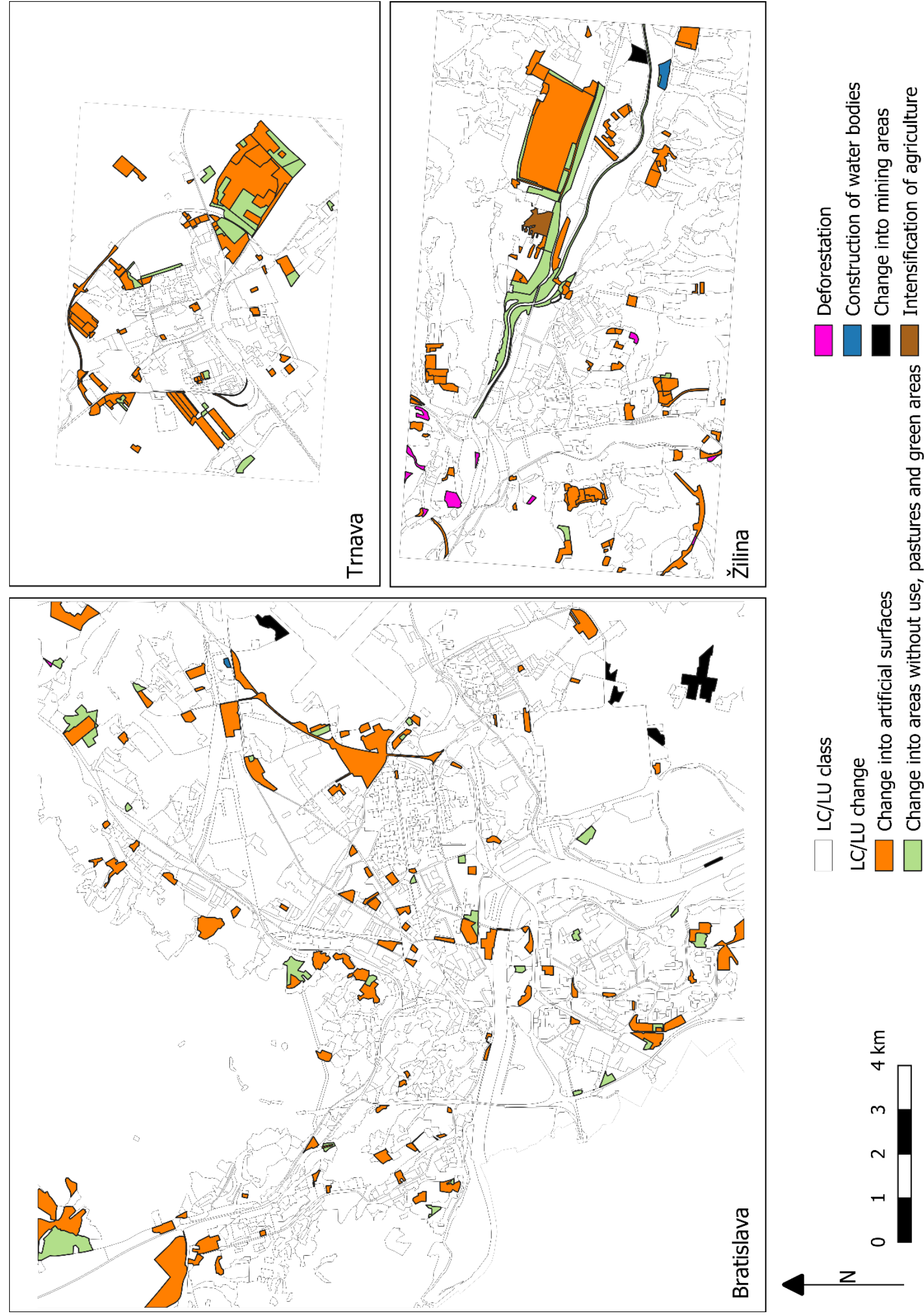
Appendix 4: Difference in modelled air temperature in $2 \mathrm{~m}$ height $\left({ }^{\circ} \mathrm{C}\right)$ between 1998 and 2016 for modelled day August 22 , 2018.
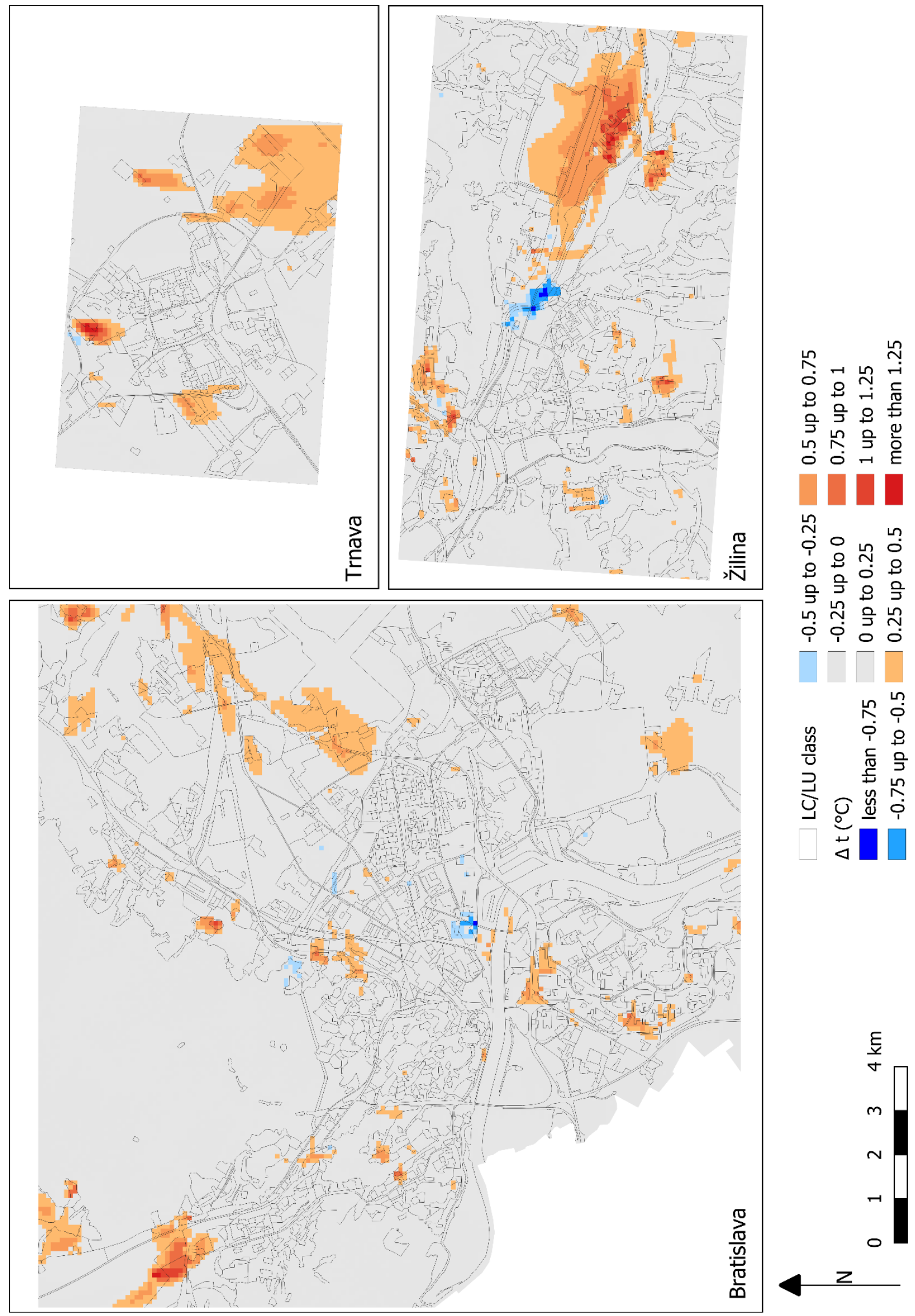